\title{
Statyba
}

\section{NUMERICAL METHODS FOR A VISCOUS INCOMPRESSIBLE HEAVY LIQUID MOTION EQUATIONS}

\section{R. Čiegis , M. Meilūnas \& A. Štikonas}

To cite this article: R. Čiegis, M. Meilūnas \& A. Štikonas (1997) NUMERICAL METHODS FOR A VISCOUS INCOMPRESSIBLE HEAVY LIQUID MOTION EQUATIONS, Statyba, 3:10, 32-36, DOI: 10.1080/13921525.1997.10531681

To link to this article: https://doi.org/10.1080/13921525.1997.10531681

曲 Published online: 26 Jul 2012.

Submit your article to this journal $₫$

Џ Article views: 34 


\section{NUMERICAL METHODS FOR A VISCOUS INCOMPRESSIBLE HEAVY LIQUID MOTION EQUATIONS}

\section{R. Čiegis, M. Meilūnas, A. Štikonas}

\section{Introduction}

Flows with free surfaces are a difficult class of nonlinear problems. In the numerical approximation of such flows, we must deal with two main problems. The first problem is non-linear Navier-Stokes problem and the second one is moving boundaries problem. Both of them require special numerical methods and coupling of them makes these difficulties even more challenging.

We consider some possible numerical methods for solving free surface flow problems for a viscous gas. The governing equations and boundary and initial conditions are given in section 2. The Pukhnachov scheme for decoupling the Navier-Stokes system and free boundary problem are discussed in sections 3 and 4. Numerical algorithms are presented in section 5, and some concluding remarks are given in section 6 .

\section{Governing equations}

A heavy viscous incompressible capillary fluid slowly flows out of a slit $h_{0}$ wide and spreads over an infinitive plate which is directed under an angle $\alpha$ to the horizon. The motion of the liquid is the result of the Poiseuille flow with a fixed flux $F$ and of the motion of the bottom with constant speed $R$ (see Fig 1). The free boundary $\Gamma$, the vector of velocity $\vec{v}$ and the pressure $p$ are unknown.

Let us give the mathematical formulation [1,2]. Choose a coordinate system $\left(x_{1}, x_{2}\right)$ as shown in Fig 1 . Then we have formula for the bottom $S_{1}=\left\{\left(x_{1}, x_{2}\right): x_{2}=0\right\}$ and for non-moving upper wall $S_{2}=\left\{\left(x_{1}, x_{2}\right): x_{1}<0, x_{2}=h_{0}\right\}$. Denote by $\Omega$ the domain occupied by the liquid. The vector of velocity $\vec{v}=\left(v_{1}, v_{2}\right)$ and pressure $p$ satisfy in $\Omega$ the NavierStokes system

$$
\begin{gathered}
-v \Delta \overrightarrow{\boldsymbol{v}}+(\overrightarrow{\boldsymbol{v}} \cdot \nabla) \overrightarrow{\boldsymbol{v}}+\nabla p=-\nabla G, \\
\nabla \cdot \overrightarrow{\boldsymbol{v}}=0
\end{gathered}
$$

and the boundary conditions

$$
\begin{array}{cc}
\left.\vec{v}\right|_{S_{1}}=(R, 0), & \left.\vec{v}\right|_{S_{2}}=(0,0), \\
\left.\vec{v} \cdot \vec{n}\right|_{\Gamma}=0, & \left.\vec{\tau} \cdot T \vec{n}\right|_{\Gamma}=0,
\end{array}
$$

where $G=g\left(-x_{1} \sin \alpha+x_{2} \cos \alpha\right), g$ is the acceleration of the gravity; $\vec{n}$ and $\vec{\tau}$ are unit vectors directed along the outward normal and the tangent to $\Gamma$, respectively, $v$ is a coefficient of viscosity; $\boldsymbol{T}=\boldsymbol{T}(\overrightarrow{\boldsymbol{v}})$ is a matrix with the elements $\left(\partial v_{i} / \partial x_{j}+\partial v_{j} / \partial x_{i}\right)$, $i, j=1,2$. We will represent the free boundary in the parametric form

$$
\Gamma=\left\{\left(x_{1}, x_{2}\right): \quad x_{1}=x(s), \quad x_{2}=y(s), s \in(0, \infty)\right\} .
$$

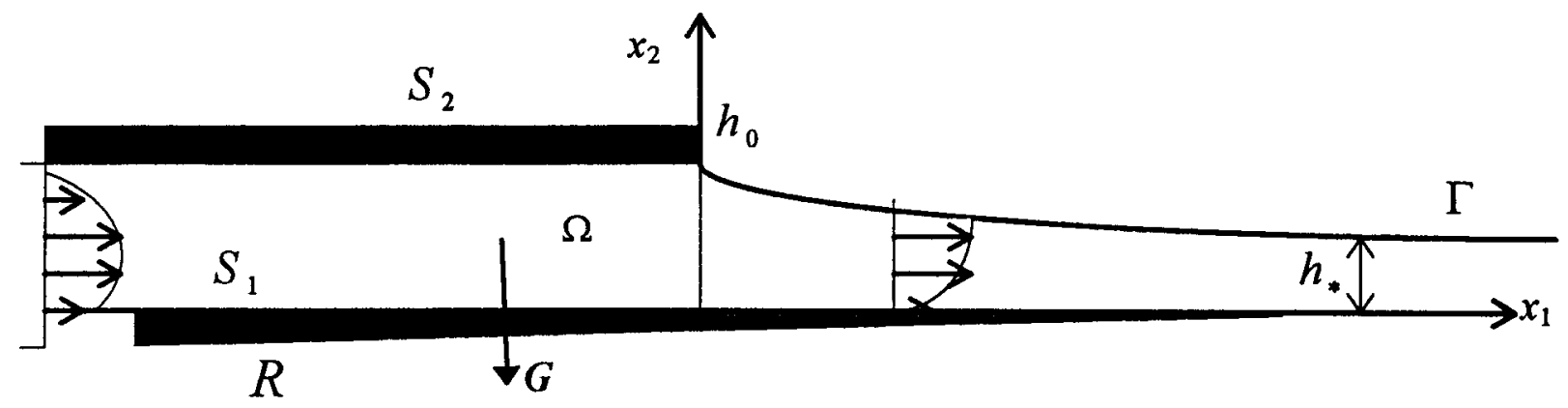

Fig 1. 
The $\Gamma$ is unknown a priori and satisfies the equations

$$
\begin{gathered}
\frac{\dot{x}(s)}{\sqrt{\dot{x}(s)^{2}+\dot{y}(s)^{2}}}=\cos \varphi(s), \\
\frac{\dot{y}(s)}{\sqrt{\dot{x}(s)^{2}+\dot{y}(s)^{2}}}=\sin \varphi(s), \\
\frac{\dot{\varphi}(s)}{\sqrt{\dot{x}(s)^{2}+\dot{y}(s)^{2}}}=\left.\sigma^{-1}(-p(x)+\vec{n} \cdot T)\right|_{x_{1}=x(s), x_{2}=y(s)}
\end{gathered}
$$

where $\varphi(s)$ is the angle between the vector $(1,0)$ and vector $\vec{\tau}$ at the point $(x(s), y(s)), \sigma$ is a coefficient of surface tension. Prescribing the contact point and assuming infinity of curve $\Gamma$, we obtain the boundary conditions

$$
x(0)=0, y(0)=h_{0}, x(\infty)=\infty
$$

(the last condition is equivalent to $\varphi(\infty)=0$ ).

To finish the mathematical formulation of the problem, the full flux $Q=F+R h_{0} / 2$ of the liquid must be prescribed:

$$
\int_{\Sigma} \vec{v} \cdot \vec{n} d x_{2}=Q,
$$

where $\Sigma=\left\{x \in \Omega: x_{1}=\right.$ const $\}$ is an arbitrary section of the domain $\Omega$.

The height $h_{*}=y(\infty)$ of the free boundary at infinity cannot be prescribed. It follows from the physical natural condition

$$
\text { " } p(x) \text { is bounded as } x_{1} \rightarrow \infty " .
$$

Hence we have to find the vector of velocity $\vec{v}$, the pressure $p$, the functions $x(s), y(s)$.

\section{Pukhnachov's scheme}

A lot of papers dealing with the mathematical analysis of stationary free boundary problems for a viscous incompressible fluid have appeared. The flows with compact and non-compact free boundaries have been considered. The general scheme is proposed by Pukhnachov [3,4]. This scheme consists in the following. Firstly, the so-called auxiliary boundary value problem (1), (2), (5), (6) for the Navier-Stokes system is considered assuming that the free boundary is given. Then the change of the solution of the auxiliary problem under a little variation of the free boundary is found out.
Finally, for small data the free boundary problem is reduced to the contraction operator equation.

Pileckas proved some results [2] about asymptotic expansion of the solution of (1)-(6) and formulates the following equation for $h_{*}=y(\infty)$

$$
g \sin \alpha h_{*}^{3}+3 R v h_{*}-3 v\left(F+R h_{0} / 2\right)=0 .
$$

This equation has a unique positive root if one of the following inequalities

$$
\begin{array}{ll}
\sin \alpha>0, & Q=F+R h_{0} / 2>0, \\
\sin \alpha=0, & Q>0, \quad R>0, \\
\sin \alpha>0, & Q=0, \quad R<0,
\end{array}
$$

holds. Let

$$
\begin{gathered}
\vec{v}^{-}=\left(\frac{R}{h_{0}}\left(h_{0}-x_{2}\right)+\frac{6 F}{h_{0}^{3}} x_{2}\left(h_{0}-x_{2}\right), 0\right), \\
\vec{p}^{-}=\left(g \sin \alpha-\frac{12 v}{h_{0}^{3}} F\right) x_{1}-g \cos \alpha x_{2}+\text { const }, \\
\vec{v}^{+}=\left(R+3 \frac{F+R h_{0} / 2-R h_{*}}{2 h_{*}^{3}} x_{2}\left(2 h_{*}-x_{2}\right), 0\right), \\
p^{+}=\left(g \sin \alpha-3 v \frac{F+R h_{0} / 2-R h_{*}}{h^{3}}\right) x_{1}- \\
-g \cos \alpha x_{2}+\text { const } .
\end{gathered}
$$

Theorem 1 [2]. Suppose that one of the conditions (8) holds and let $h *$ be a unique root of the cubic equation (7). For sufficiently small $F, R$ and $\alpha$, the problem (1), (2), (5), (6) has a unique solution $(\vec{v}, p)$, which admits the asymptotic expansion $\vec{v}=\zeta\left(-x_{1}\right) \vec{v}^{-}(x)+\zeta\left(x_{1}\right) \vec{v}^{+}(x)+\vec{u}(x)$, $p=\zeta\left(-x_{1}\right)\left(g \sin \alpha-\frac{12 v F}{h_{0}^{3}}\right) x_{1}-g \cos \alpha\left(x_{2}-h_{*}\right)+q(x)$.

Here $\zeta(t)$ is an infinitely differentiable function with $\zeta(t)=1$ for $t \geq 2$, and $\zeta(t)=0$ for $t \leq 1$. Functions $\vec{u}$, $q$ exponentially vanish when $\left|x_{1}\right| \rightarrow+\infty$ and $x(s) \rightarrow s$, $y(s) \rightarrow h_{*}$ when $s \rightarrow+\infty$. Moreover, the norms of $\vec{u}$, $q$ are less than $C_{1}(F, R, \alpha)$ with the constant $C_{1}$ being small for small $|F|,|R|$ and $\alpha$ :

$$
\|\vec{u}\|_{C_{\delta}^{2+\delta}(\Omega ; \mu)}+\|\nabla q\|_{C_{z-2}^{\delta}(\Omega ; \mu)} \leq C_{1}(F, R, \alpha), \quad \delta \in(0,1),
$$


where the norm is defined as [2]

$$
\|u\|_{C_{r}^{l}(\Omega ; \mu)}=\|u\|_{C_{r}^{\prime}\left(\Omega_{0}\right)}+\left\|u \exp \left(\mu\left|x_{1}\right|\right)\right\|_{C^{\prime}\left(\Omega^{+}\right)}
$$

for $\mu>0$ and $>0$ being a non-integer, $0<r<l$.

The next part of the Pukhnachov scheme is devoted to variation of a free boundary. Let $\Gamma^{(i)}, i=1,2$ be two curves satisfying

$$
\Gamma^{(i)}-h_{*} \in C_{1+\delta}^{3+\delta}\left(R_{+}^{1} ; \mu\right)
$$

and conditions

$$
\begin{aligned}
& \left\|x^{(2)}(s)-x^{(1)}(s)\right\|_{C_{1+\delta}^{3+8}\left(R_{+}^{1} ; \mu\right)}<\varepsilon, \\
& \left\|y^{(2)}(s)-y^{(1)}(s)\right\|_{C_{1+\delta}^{3+8}\left(R_{+}^{1} ; \mu\right)}<\varepsilon
\end{aligned}
$$

are valid.

Theorem 2 [2]. Let the conditions of Theorem 1 be valid. Then there exists a number $\varepsilon_{0}$ such that for $\varepsilon \in\left(0, \varepsilon_{0}\right)$ (see, (9)) the functions

$$
H^{(i)}=\left.\left(-q^{(i)}(\boldsymbol{x})+\left(\overrightarrow{\boldsymbol{n}} \cdot \boldsymbol{T}\left(\overrightarrow{\boldsymbol{v}}^{(i)}\right) \overrightarrow{\boldsymbol{n}}\right)\right)\right|_{\Gamma^{(i)}}
$$

satisfy the estimate

$$
\begin{gathered}
\left\|H^{(2)}-H^{(1)}\right\|_{C_{\delta-1}^{1+8}\left(R_{+}^{1} ; \mu\right)} \leq \\
C_{2}\left(\left\|x^{(2)}(s)-x^{(1)}(s)\right\|_{C_{1+8}^{3+8}\left(R_{+}^{1} ; \mu\right)}+\right. \\
\left.+\left\|y^{(2)}(s)-y^{(1)}(s)\right\|_{C_{1+8}^{3+8}\left(R_{+}^{1} ; \mu\right)}\right)
\end{gathered}
$$

with constant $C_{2}=C_{2}(F, R, \alpha)$ being small for small $|F|,|R|, \alpha$ and independent of $\varepsilon \in\left(0, \varepsilon_{0}\right)$.

Now we consider the free boundary problem. Let denote $\beta=g \sigma^{-1} \cos \alpha$. By virtue of Theorem 1 the function $\left.(-q(x)+\vec{n} \cdot T \vec{n})\right|_{\Gamma}$ exponentially vanishes as $s \rightarrow \infty$. Omitting this function and taking as a parameter in the system (3) the length of arc of the initial approximation $\Gamma_{0}$ to the free boundary $\Gamma$, we obtain the following boundary value problem

$$
\begin{gathered}
\dot{x}_{0}(s)-\cos \varphi_{0}(s)=0, \\
\dot{y}_{0}(s)-\sin \varphi_{0}(s)=0, \\
\dot{\varphi}_{0}(s)-\beta\left(y_{0}(s)-h_{*}\right)=0, \\
x_{0}(0)=0, \quad y_{0}(0)=h_{0}, y_{0}(\infty)=h_{*} .
\end{gathered}
$$

Theorem 3 [2]. Let $\left|h_{0}-h_{*}\right|<2 / \sqrt{\beta}$. Then the problem (11) has a unique infinitely differentiable solution $\left(x_{0}, y_{0}, \varphi_{0}\right)$ such that

$$
\begin{gathered}
x_{0}(s)=s+O(1), \dot{x}_{0}(s)=1+O(\exp (-\sqrt{\beta} s)), \\
y_{0}(s)=h_{*}+O(\exp (-\sqrt{\beta} s)), \varphi_{0}(s)=O(\exp (-\sqrt{\beta} s))
\end{gathered}
$$

as $s \rightarrow \infty$.

The angle between the curve $\Gamma_{0}$ and the wall $S_{2}$ is defined by the formula $\theta=\pi+\varphi_{0}(0)$.

\section{Method of successive approximation}

Let $\gamma=(x(s), y(s), \varphi(s))$. We rewrite the problem (1)-(6) in the following operator form

$$
\begin{gathered}
\Phi(\vec{v}, \vec{v}, p, \gamma)=0, \\
\Psi(\vec{v}, p, \gamma)=0,
\end{gathered}
$$

where $\Phi$ defines the Navier-Stokes problem in the region $\Omega$ with a given boundary $\Gamma=\gamma$ :

$$
\Phi(\vec{v}, \vec{w}, p, \gamma) \equiv\left\{\begin{array}{c}
-v \Delta \vec{v}+(\vec{w} \cdot \nabla) \vec{v}+\nabla p+\nabla G \\
\nabla \vec{v} \\
\text { boundary conditions on } \gamma
\end{array}\right.
$$

and $\Psi$ defines the free surface equation (3) for given velocity $\vec{v}$ and pressure $p$ :

$$
\begin{gathered}
\Psi(\vec{v}, p, \gamma) \equiv \\
\frac{\dot{x}(s)}{\sqrt{\dot{x}(s)^{2}+\dot{y}(s)^{2}}}-\cos \varphi(s) \\
\frac{\dot{y}(s)}{\sqrt{\dot{x}(s)^{2}+\dot{y}(s)^{2}}}-\sin \varphi(s) \\
\frac{\dot{\varphi}(s)}{\sqrt{\dot{x}(s)^{2}+\dot{y}(s)^{2}}-\beta\left(y(s)-h_{*}\right)-\sigma^{-1} H(\vec{v}, p, \gamma)} \\
x(0)=0, y(0)=h_{0}, \\
\left.\varphi(\infty)=0 \text { (or } y(\infty)=h_{*} \text { or } x(\infty)=\infty\right)
\end{gathered}
$$

where

$$
H(\vec{v}, p, \gamma)=-p(x)-g \cos \alpha\left(x_{2}-h_{*}\right)+\left.(\vec{n} \cdot T(\vec{v}) \vec{n})\right|_{\gamma} .
$$

For convenience of notation, boundary conditions are incorporated into the definition of operators $\Phi, \Psi$.

We take as initial approximation $\vec{v}_{0} \equiv(0,0)$, $p_{0} \equiv 0, \gamma_{0}$, where $\gamma_{0}$ is the solution of the problem (11). Let $(j-1)$ th approximation $\left(\vec{v}_{j-1}, p_{j-1}, \gamma_{j-1}\right)$ is build. We solve problem (12) with given free boundary $\gamma_{j-1}$ : 


$$
\Phi\left(\vec{v}_{j}, \vec{v}_{j}, p_{j}, \gamma_{j-1}\right)=0
$$

in the domain $\Omega_{j-1}$ and get $\vec{v}_{j}, p_{j}$. Then we solve problem (13) with given $\overrightarrow{\boldsymbol{v}}_{j}, p_{j}$ :

$$
\Psi\left(\vec{v}_{j}, p_{j}, \gamma_{j}\right)=0
$$

and get $\gamma_{j}$, ie we obtain the next approximation $\left(\vec{v}_{j}, p_{j}, \gamma_{j}\right)$ of the solution of our problem.

Let denote constants $|F|,|R|$ and $\alpha$ as $\alpha^{*}$. It follows from $[1,2]$ that

$$
\left(\vec{v}_{j}, p_{j}, \gamma_{j}\right) \rightarrow\left(\vec{v}_{*}, p_{*}, \gamma_{*}\right)
$$

for $\alpha^{*} \ll 1$, where $\left(\vec{v}_{*}, p_{*}, \gamma_{*}\right)$ is the solution of the problem (1)-(6).

\section{Discrete scheme}

We approximate differential equations by discrete scheme. There are many possibilities to choose from, ie finite difference schemes, finite volume schemes, finite element schemes (see $[5,6]$ ). Discretization yields a system of non-linear algebraic equations

$$
\begin{array}{r}
\Phi_{h}(\vec{V}, \vec{V}, P, \Gamma)=0, \\
\Psi_{h}(\vec{V}, P, \Gamma)=0 .
\end{array}
$$

Boundary conditions. In order to get a finite dimension algebraic problem, we must state auxiliary boundary conditions at some finite points $x_{1}=X_{1 L}$ and $x_{1}=X_{1 R}$. Asymptotic expansions from Theorem 1 can be used to define needed boundary conditions. The error introduced by such truncation of the region is estimated by solving the same problem in a larger region.

Algorithm 1. In this algorithm we follow the idea of the Pukhnachov method. The solution of stationary problem (15)-(16) is obtained by the following iterative method. Let assume that $\Gamma_{j-1}$ is given. The new approximations $\vec{V}_{j}, P_{j}, \Gamma_{j}$ are defined as

$$
\begin{array}{r}
\Phi_{h}\left(\vec{V}_{j}, \vec{V}_{j}, P_{j}, \Gamma_{j-1}\right)=0, \\
\Psi_{h}\left(\vec{V}_{j}, P_{j}, \Gamma_{j}\right)=0 .
\end{array}
$$

The first subproblem (17) is the steady NavierStokes problem in given region with a fixed free boundary. It is solved by some iterative method which can be regarded as solving an unsteady problem until steady state is reached:

$$
\frac{\vec{V}_{k, j}-\vec{V}_{k-1, j}}{\tau_{k}}+\Phi_{h}\left(\vec{V}_{k, j}, \vec{V}_{k, j}, P_{k, j}, \Gamma_{j-1}\right)=0 .
$$

We will call this iteration as outer iteration for the Navier-Stokes problem. Due to the non-linearity and coupling between velocity and pressure we must use inner iterations to find $\vec{V}_{k, j}$. The obtained system of linear equations is also usually solved by iterative method, eg GMRES method. The efficiency of this step depends on definition of tolerances within which the iterations must satisfy.

The new approximation of the boundary $\Gamma_{j}$ is defined by solving the second subproblem (18). As it follows from equations (3) and boundary conditions (4) we have a system of ODE with boundary conditions given at $s=0$ and $s=\infty$ In order to get a finite problem, we formulate the third boundary condition at $s=S$, where $S$ sufficiently large. The shooting method is used to solve obtained system.

Algorithm 2. We modify the previous algorithm and march in time without requiring full satisfaction of the non-linear equations at each outer iteration

$$
\begin{gathered}
\frac{\vec{V}_{j}-\vec{V}_{j-1}}{\tau_{j}}+\Phi_{h}\left(\vec{V}_{j}, \vec{V}_{j-1}, P_{j}, \Gamma_{j-1}\right)=0, \\
\Psi_{h}\left(\vec{V}_{j}, P_{j}, \Gamma_{j}\right)=0 .
\end{gathered}
$$

The realization of this algorithm requires to solve the of linearized Navier-Stokes equation and of the free surface equation.

The convergence of iterative methods defined in Algorithm 1, 2 can be proved for sufficiently small values of flow parameters. The method of numerical experiments is used to find precise bounds of the convergence region.

Algorithm 3. The previous Algorithm 2 can be considered as a variant of the Gauss-Seidel method for solving a coupled system of non-linear equations

$$
\left\{\begin{array}{c}
\Phi_{h}(\vec{V}, \vec{V}, P, \Gamma)=0 \\
\Psi_{h}(\vec{V}, P, \Gamma)=0
\end{array}\right.
$$

The Newton method and its modifications also can be used to solve this system

$$
\left(\begin{array}{l}
\vec{V} \\
P \\
\Gamma
\end{array}\right)_{j}=\left(\begin{array}{l}
\vec{V} \\
P \\
\Gamma
\end{array}\right)_{j-1}-\tau_{j} J_{j}^{-1}\left(\begin{array}{l}
\Phi_{h} \\
\Psi_{h}
\end{array}\right)_{j-1} .
$$


The efficiency of realization of this method depends on a possibility to solve economically a system of linear equations with the matrix $\boldsymbol{J}$.

\section{Concluding remarks}

The convergence of Algorithm 2 can be linked with the existence of stable solution of the problem (1)-(3). Then the divergence of iterative method means that a solution of stationary solution (if any exists) is nonstable. Such solutions can be find by Algorithm 3 .

At the time this research was provided, the authors were employed at the Institute of Mathematics and Informatics, Vilnius Gediminas Technical University, and Kaunas Vytautas the Great University.

\section{References}

1. К.И. Пилецкас. К задаче о течении тяжелой вязКой несжимаемой жидкости со свободной некомпактной границей // Литовский математический сборник, $28(2), 1988$, с. $315-333$.

2. K.I. Pileckas. On plane motion of a viscous incom-presible capillary liquid with a noncompact free boundary // Arch. Mech., 41(2-3), 1989, p. 329-342, Warszawa.

3. В.В. Пухначев. Плоская стационарная задача со свободной границей для уравнений Навье-Стокса // Прикл. механ. и техн. физикн, 3, 1972, с. 91-102.

4. В.В. Пухнатев. Переменные Мизеса в задачах со свободной границей для уравнений Навье-Стокса // ДАН СССР, 210, 1973, с. 298-301.

5. Ferziger, M.Peric. Computational methods for fluid dynamics. Springer Verlag, Berlin, Heidelling, New York, 1996.

6. Heywoodm, R. Rannacher. Finite element approximation of the nonstationary Navier-Stokes problem. I. // SIAM J. Numer. Anal., 19, 1982, p. 275-311.

Iteikta 19970220

\section{SUNKIOJO NESPŪDŽIOJO SKYSČIO TEKĖJIMO LYGČIUU SKATTINIAI SPRENDIMO METODAI}

\section{R. Čiegis, M. Meilūnas, A. Štikonas}

Sa n trauka

Darbe nagrinėjamas sunkiojo nespūdžiojo skysčio tekèjimo uždavinys, kai dalis paviršiaus yra laisva. Skaitiškai sprendžiant tokius uždavinius svarbiausios dvi problemos. Pirmoji - netiesinio Navjè-Stokso uždavinio diskrečioji aproksimacija srityje su fiksuotu paviršiumi, o antroji problema - judančiu paviršiu skaitinis aproksimavimas. Darbe suformuluoti trys algoritmai pagrindiniam uždaviniui spręsti. Pirmajame panaudota konstruktyvi Puchnačiovo diferencialinio uždavinio sprendinio egzistencijos jrodymo schema. Siuo metodu iteracinio proceso metu netiesinis Navjè-Stokso uždavinys sprendžiamas fiksuotoje erdvès srityje ir tikslinamas laisvasis srities paviršius. Tai išskaido uždavini $\mathfrak{i}$ du paprastesnius uždavinius, kuriu kiekvieno sprendimas yra pakankamai nuodugniai išnagrinètas literatūroje. Tiriama Puchnačiovo metodo konvergavimo sritis.

Antrasis algoritmas gaunamas sprendžiant linearizuotą nestacionary Navjè-Stokso uždavini, t.y. nereikalaujame, kad kiekvienoje išorinejje iteracijoje netiesinè diskrečioji Navjè-Stokso sistema būtu tiksliai išspredžiama. Sio algoritmo vienos iteracijos realizacija yra efektyvesné, lyginant su pirmuoju algoritmu, tačiau iteraciju skaičius didesnis.

Abiejų pirmujų algoritmų konvergavimas gali büti naudojamas diferencialinio uždavinio sprendinio stabilumo tyrimui.

Trečiajame algoritme realizuota Niutono metodo modifikacija. Šiame algoritme nèra atskiriamos NavjèStokso ir laisvojo paviršiaus lygtys. Gautoji netiesinių lygčiu sistema sprendžiama Gauso-Zeidelio metodu.

Svarbus skaičiavimo eksperimento uždavinys - palyginti visy trijų algoritmų konvergavimo sritis.

Raimondas ČIEGIS. Doctor Habil, Professor. Department of Mathematical Modelling. Vilnius Gediminas Technical University (VGTU), 11 Saulètekio Ave, 2040 Vilnius. Doctoral thesis in 1985, Doctor's Habil degree in 1993. Research interests: numerical methods for non-linear PDE, adaptive difference schemes and numerical modelling in physics, biophysics, ecology.

Mečislovas MEILŪNAS. Doctor, Associate Professor. Department of Mathematical Modelling. Vilnius Gediminas Technical University (VGTU), 11 Saulétekio Ave, 2040 Vilnius. Doctoral thesis in 1995. Research interests: numerical methods for non-linear problems, mathematical modelling in medicine.

Artūras ŠTIKONAS. Doctor, Researcher. Department of Numerical Analysis. Institute of Mathematics and Informatics, 4 Akademijos, Vilnius. Main theoretical results deal with the investigation of finite-difference schemes for symmetrical motion viscous gas dynamics equations. Research interests: numerical methods for non-linear problems, mathematical modelling of non-linear systems. 